\title{
10 health stories that mattered in 2014
}

- EBOLA: West Africa experienced the largest Ebola outbreak in history, and Canada is playing a prominent role in the fight against the deadly virus. Canadian researchers contributed to the creation of an Ebola vaccine (VSV-EBOV) and two therapies (TKM-Ebola and ZMapp). Médecins Sans Frontières Canada became a strong advocate for improving the international effort to combat the epidemic and provide medical care to people infected with the virus.

- END OF LIFE: Quebec became the first province in Canada to legalize physician-assisted death. On June 5, the province's government voted 94:22 in favour of passing Bill 52, an "Act respecting end-of-life care." The controversial bill, which underwent 57 amendments leading up to the vote, permits doctors to administer drugs to hasten death for terminally ill patients.

- MEDICAL MARIJUANA: Health Canada changed its medical marijuana regulations on April 1, allowing only licensed commercial growers to produce the drug. Due to lack of clinical evidence of safety and efficacy, a cautious approach to prescribing the drug has been recommended by the Canadian Medical Association, The College of Family Physicians of Canada and provincial physician colleges. Some doctors are worried that becoming "gatekeepers" to medical marijuana will strain their relationships with patients.

- E-CIGARETTES: Concerns that e-cigarettes may actually encourage tobacco use rather than supplant it prompted provincial and territorial health ministers to call for tougher controls on the increasingly popular products. Bans on e-cigarette use (or "vaping") in public spaces and sales to minors were proposed in several cities, including Toronto and Vancouver. The devices have become so common that Oxford Dictionaries chose "vape" as the word of the year for 2014.

- MEASLES: Outbreaks of measles in several provinces in March and April prompted calls for improved vaccination coverage. British Columbia reported 300 cases, and 450 students at a Christian school were quarantined. Herd immunity requires vaccination rates of $95 \%$, but in some areas of BC the rate is only $88 \%$. Canada ranks 28th of 29 of the richest countries with respect to childhood vaccinations rates.

- SOLDIERS' HEALTH: More Canadian soldiers died from suicide than in combat (160:138) during the war in Afghanistan, prompting the Department of National Defence to hire 54 mental health professionals. The federal government will also spend $\$ 400$ million over six years to expand mental health initiatives. A new Statistics Canada survey indicated that $16.5 \%$ of Canadian soldiers had experienced mental health issues in 2013.

- HEALTH ACCORD: The expiry of the 10-year-old, \$41-billion health accord between the federal government and provinces and territories on Mar. 31 prompted concerns about the erosion of national, universal health care. The federal government refused to broker a new deal; instead transfers will rise by at least 3\% annually, with no conditions on how that money is spent. Physician leaders said the change could increase health inequality.

- REFUGEE HEALTH: Federal cuts to refugee health care were ruled unconstitutional and "cruel and unusual treatment" by a Federal Court justice in July. The federal government restored access to basic health care in November, but is appealing the court's decision. Full access to Canadian health care will be limited until the case is resolved.

- RESEARCH GRANTS: Researchers were outraged at news in December that half of all grant monies from the Canadian Institutes of Health Research will be contingent on researchers obtaining matching funds externally. Contrary to advice from two expert panels, CIHR is also cutting its institute advisory boards from 13 to 4 . The final reports of the expert panels also came under fire for not evaluating the effect of recommended changes on the Institute of Aboriginal Peoples' Health.

- ABORTION AVAILABILITY: When the private Morgentaler clinic in New Brunswick closed on July 31, the NB Medical Society objected to the protocol that restricted abortion access at hospitals. In November, the province struck down the abortion restrictions. Access to abortion services is uneven across Canada according to a new survey, but nowhere more so than in Prince Edward Island, which has no services.

CMAJ 2015. DOI:10.1503/cmaj.109-4967 